\title{
Scope of Organic Farming Vegetable Cultivation
}

\author{
C. Manoharan \\ Professor, AMET Business School, AMET University, Chennai, Tamil Nadu, India
}

\begin{abstract}
Article Info

Volume 8, Issue 5

Page Number : 220-224

Publication Issue

September-October-2021

Article History

Accepted : 18 Sep 2021

Published : 30 Sep 2021

Agriculture began organically. For many centuries, humans farmed without synthetic biocides or inorganic fertilizers, relying on organic fertilizers derived from plants and animals, and protecting crops from pests and diseases using naturally-occurring materials. From the second half of the nineteenth century growers around the world successfully developed and refined farming systems that relied on synthetic biocides or inorganic fertilizers.

Keywords : Mineral Grade Rock Additives, Nutrient Mobilization, Mineral Grade Rock Additives, Green Manures, Compost, Vermin -Compost, Organic Cakes, Bio-Fertilizers And Biodynamic Preparations.
\end{abstract}

\section{INTRODUCTION}

India is an agrarian economy and the agriculture sector in India contributes about 17 percent of country's GDP and provides employment to approximately two third of the population. India with its varied agro-climatic zones is amenable to grow a wide variety of vegetable crops. India, with production level of 176.2 million metric tonnes of vegetables, is the second largest vegetable producer country after China, in the world, accounting for $14 \%$ of the total world vegetable production. Vegetables are important constituents of Indian diet as they are rich source of carbohydrate, proteins, vitamins, minerals, glucosinolates, antioxidants, fibre, etc. Vegetables and fruits are consumed for nutrition, maintenance of health and many for their therapeutic values and prevention of diseases. The indiscriminate use of chemical inputs in agriculture fears/concerns the contamination of foods with agrochemicals. The consumers are concerned about the vegetables they eat. Both the international and domestic communities are becoming more and more conscious on issues like residues of poisonous agrochemicals in vegetables and their associated health and environmental hazards. This therefore made us to think about alternate form of agriculture to produce food devoid of contaminants. Organic agriculture is one among the broad spectrum of production methods that are supportive of the environment and restricts the use of synthetic inputs.

As per the definition of the USDA study team on organic farming "organic farming is a system which avoids or largely excludes the use of synthetic inputs (such as fertilizers, pesticides, hormones, feed additives etc) and to the maximum extent feasible rely upon crop rotations, crop residues, animal manures, off-farm organic waste, mineral grade rock additives 
and biological system of nutrient mobilization and plant protection". In another definition FAO suggested that "Organic agriculture is a unique production management system which promotes and enhances agro-ecosystem health, including biodiversity, biological cycles and soil biological activity, and this is accomplished by using on farm agronomic, biological and mechanical methods in exclusion of all synthetic off-farm inputs".

\section{METHODS AND MATERIAL}

\section{Growth of Organic vegetable}

Lettuce seedlings grown with organic fertiliser showed an increased growth rate compared to those grown with traditional fertiliser. By contrast, cabbage and cauliflower seedlings grown with organic fertiliser showed a reduced growth rate (Botrini et al. 2004 ). The optimum $\mathrm{pH}$ of growing media for lettuce in organic cultivation was close to 6 and the optimum electrical conductivity (EC) was lower than $2 \mathrm{dSm}-1$. Increasing $\mathrm{pH}$ and especially EC reduced growth, and conductivity about $3 \mathrm{dSm}-1$ or higher had an inhibitory effect on growth when pH was about 7 or higher (Loncaric et al. 2009 ) . The impact of row covers on cucumber plant growth was signi fi cant. Use of row covers increased vine length, flower count, leaf area and leaf count (Nair and Ngouajio 2010 ). Soil amendment treatments consisted of combinations of the following: poultry compost, poultry litter, dairy compost, dairy manure, blood meal, feather meal, and Fertrell ${ }^{\mathrm{TM}}$ 5-5-3. Poultry compost resulted in the greatest plant growth in all trials (Rauton 2007 ). Overall, organic cultivation positively affected vegetable growth in $43 \%$ of studies from the literature and negatively affected growth in $57 \%$ of studies.

\section{Nutritional quality}

Regarding vegetables (carrot, beetroot, lettuce, kale, leek, turnip, onion, celeriac and tomato) a trend has been observed for higher levels of iron and magnesium expressed on a nutritional quality and safety of organic food (Lairon 2010 ) . Lettuce seedlings grown with organic fertiliser had a higher $\mathrm{N}$ and $\mathrm{K}$ uptake than those grown with traditional fertilisation. By contrast, cabbage and cauliflower seedlings grown with organic fertiliser showed a reduction of nutrient content, particularly at the end of growth period (Botrini et al. 2004 ).

Cabbage and cauliflower seedlings grown with organic fertiliser showed a reduction of chlorophyll content compared with traditional fertilization, particularly at the end of the growth period (Botrini et al. 2004 ) . Regarding water-soluble vitamins, the most studied has been Vitamin C (ascorbic acid), a key vitamin for which higher daily intakes are recommended. Studies on tomato, celeriac and kale showed higher vitamin $C$ levels in organicallygrown products. In contrast, no difference was found during studies in leek, carrot or beetroot (Lairon 2010 ). The vitamin $\mathrm{C}$ content of an organic fruit or vegetable is $27 \%$ more, on average, than a comparable conventionally grown fruit or vegetable (Worthington 2001 ) . Similarly, in leafy vegetables, leaf concentrations of vitamin $\mathrm{C}$ were significantly higher in organic-fertilized than in chemically-fertilized vegetables (Xu et al. 2003 ). By contrast, the vitamin $\mathrm{C}$ content was not influenced by the growing system in the study of Fjelkner-Modig et al. ( 2000 ). These results may be due to the vitamin con-tent of a plant depending on a number of factors such as climate, genetic properties, fertilizer and soil.

\section{Organic Vegetables}

Depending on season, organic vegetables overall may contain at least $30-50 \%$ less nitrates than conventional ones (Worthington 2001 ; Porto et al. 2008 ; Lairon 2001). This was confirmed by a lower nitrate content of plants when the percentage of organic $\mathrm{N}$ increased (Mahmoud et al. 2009 ). The 
analysis of the scientific literature showed that, in most of the experiments, nitrate content clearly reduced by using organic procedures (Pimpini et al. 2005 ). In leafy vegetables, leaf concentrations of nitrate were lower in organic-fertilized than in chemical-fertilized vegetables (Xu et al.2003).

\subsection{Concept and Definition}

This is also called 'ecological farming' in some northern European countries. Organic farming must ensure building up of a satisfactory level of $\mathrm{P}$ (through rock phosphates) in the surface and subsoil and an optimal level of organic carbon in the soil. The ultimate aim is to feed the soil rather than the crops to maintain soil health and it is a means of giving back to the nature what has been taken from it (Funtilana, 1990). Since it is evident that soil fertility and crop production cannot be sustained unless the nutrients removed from soil by the crops are replenished. In real sense organic farming production system aims at promoting and enhancing agroecosystem health, biodiversity, biological cycles, and soil health. Thus, to maintain a productive and quality organic system, management of soil organic matter is critical. There are many organic sources which contribute organic matter to the soil. Single source of nutrient not suffices to maintain productivity and quality in organic farming system, so a combination of different organic amendments may be required for a successful organic cultivation (Singh et al., 2007).

Recently, food and Agricultural organization of the united Nation (FAO) focused organic farming as resource saving agricultural crop production. As per FAO definition, the organic farming is to achieve acceptable profit, high and sustained production levels, and conserves the environment. It further argues that conservation agriculture is based on enhancing natural biological processes occurring above and below the soil surface. They go beyond zero tillage and provide a range of technology and management options. Organic farming practices are applicable to virtually all the crops, including cereals, horticulture and plantations crops.

\subsection{Need for organic farming}

Agriculture is facing new challenges, including the development of organic production and the introduction of new regulations or private standards. Agriculture is also affected by sustainable development trends that make it necessary to minimize the environmental impact of cultural practices (Nesme et al., 2006). Population growth and expanding demand for agricultural products constantly increase the pressure on land and water resources.Increased soil carbon means increased soil organic matter, improved soil water holding capacity, conservation of natural resources and hence better crop production. Crop residue management, notillage, efficient management of nutrients through organic sources, precision farming, efficient management of water, and restoration of degraded soils all contribute to a sustainable agriculture.

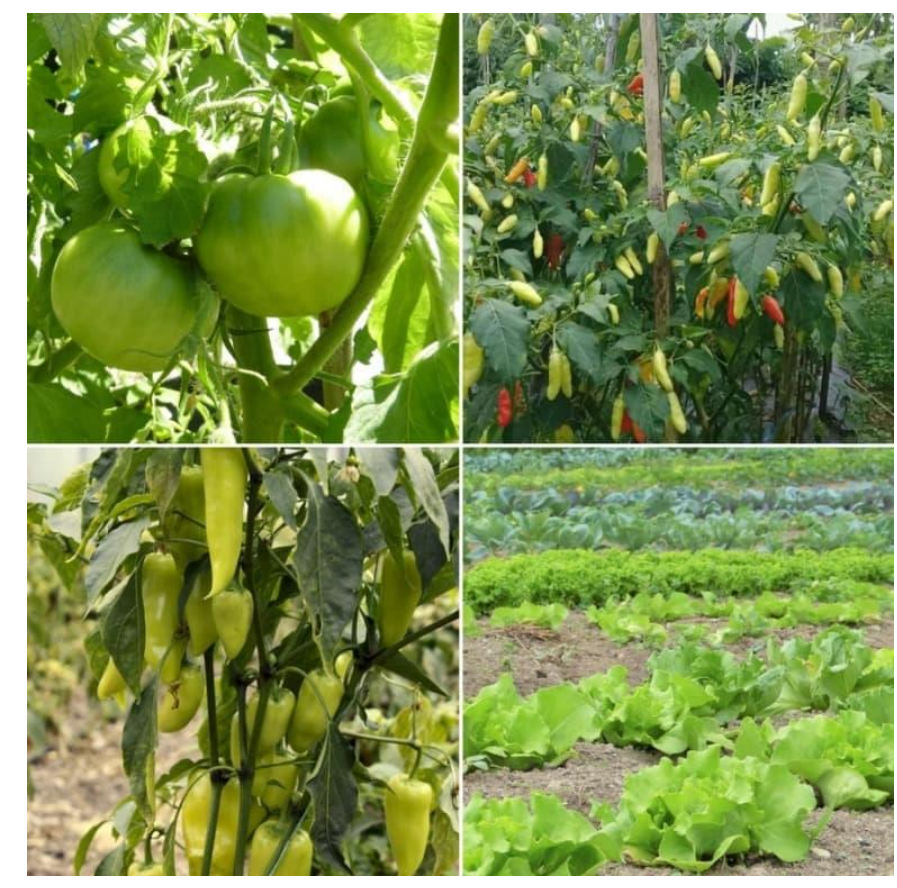

Fig 3.2 Organic farming 


\section{Benefit of Organic Farming}

1. Greater rural incomes leading to check in ruralurban migration.

2. Organically grown fruits are believed to be healthier and nutritionally superior.

3. Organically grown fruits are more resistant to insect-pest and diseases.

4. Organic manures create optimal condition in soil for higher yields.

5. Improve plant growth and physiological activities of plants.

6. Enhance biodiversity and improve the value of experimental services.

7. Improves habitation of beneficial organisms which improve soil biological, physical and chemical properties, and contribute in increasing crop productivity.

8. Reduction in poverty and enhance food and nutritional security due to higher, more stable yields and longer food prices.

9. Improve the sustainability of different production systems.

10. Supply all the nutrients required by plants.

\section{CONCEPTUAL FRAMEWORK}

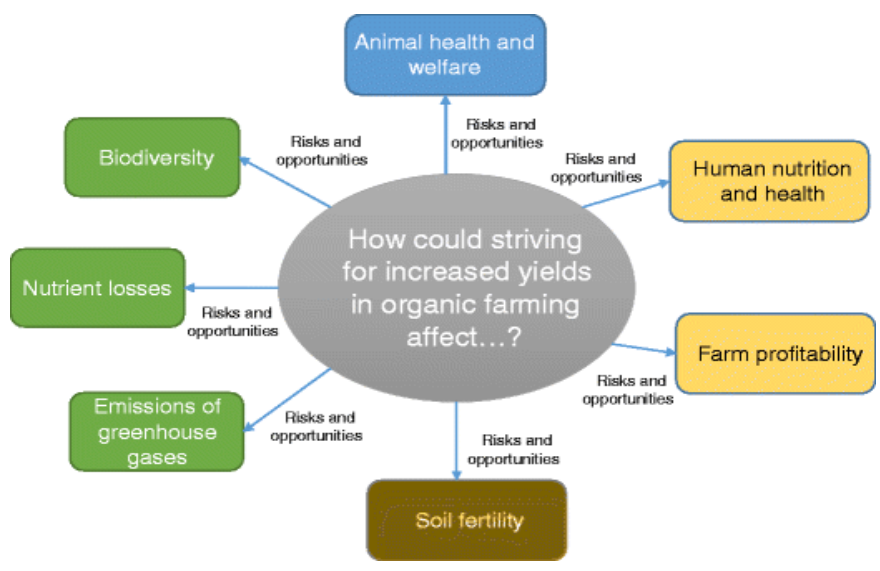

Figure 4.1 The Conceptual Framework of the Research Work.

\section{CONCLUSION}

Organic production of food commodities is the need of the hour. At present all over the world organic produce fetches a fancy price and local demand for fresh, safe and quality vegetables is very high, which can hardly be met by the vegetable produced with the injudicious application of chemical fertilizers in intensive cultivation practices. The requirement of organic produce can be fulfilled, if the process of adoption of organic farming techniques is strengthened and sufficient quantity of organic produce is made available in market; as a result of this the unaffordable foods will be affordable to the people. Even it has been seen that yields obtained with the application of all scientific techniques of organic farming from organic farms is equal to those on conventional farms, although average production is $10-15 \%$ lower on organic farms. This is due to lack of research and adequate extension recommendations in organic systems, and lower intensity of resource use in organic farming where there is dependence on internal resources and limited import of fossil fuelderived materials from outside the farm. An organic farming strategy can be profitable if the production costs are lower and if price premiums are available.

\section{REFERENCES}

[1]. Masarirambi MT, Hlawe MM, Oseni OT, Sibiya TE (2010) Effects of organic fertilizers on growth, yield, quality and sensory evaluation of red lettuce ( Lactucasativa L.) 'VenezaRoxa'. AgricBiol J North Am 1(6):1319-1324 .

[2]. Muramoto J (1999) Comparison of nitrate content in leafy vegetables from organic and conven-tional farms in California. Center for Agroecology and Sustainable Food Systems University of California, Santa Cruz Santa Cruz, CA 95064 831/459-2506, 64 pp.

[3]. G.Ramachandran, C. K. Dixit, K. Kishore and A. Arunraja, "Performance Analysis Of Mantissa 
Multiplier And Dadda Tree Multiplier And Implementing With Dsp Architecture," 2021 International Conference on Artificial Intelligence and Smart Systems (ICAIS), 2021, pp. 1583-1587, doi: 10.1109/ICAIS50930.2021.9395883.

[4]. Nair A, Ngouajio M (2010) Integrating rowcovers and soil amendments for organic cucumber pro-duction: implications on crop growth, yield, and microclimate. HortScience 45(4):566-574.

[5]. Ngouajio M, McGiffen MEJ, Hutchinson CM (2003) Effect of cover crop and management system on weed populations in lettuce. Crop Prot 22(1):57-64

[6]. Oliveira EQ Souza RJ, Cruz MCM, Marques VB, Franca AC (2010) Productivity of lettuce and rocket in intercropping system under organic and mineral fertilization. Hortic Bras 28:36-40.

[7]. Pavla B, Pokluda R (2008) In fluence of alternative organic fertilizers on the antioxidant capacity in head cabbage and cucumber. Not Bot HortAgrobotCluj 36(1):63-67.

[8]. Pimpini F, Gianquinto G, Sambo P (2005) Organic vegetable production: evolution, base principles and quality of products. ItalusHortus 12(4):31-44.

[9]. Porto ML, Alves JC, Souza AP, Araujo RC, Arruda JA (2008) Nitrate production and accumulation in lettuce as affected by mineral nitrogen supply and organic fertilization. Hortic Bras 26:227-230.

[10]. Rauton RSW (2007) Soil fertility management in organic vegetable production. Partial ful fi llment of the requirements for the degree Master of Science Plant and Environmental Sciences of the Graduate School of Clemson University, $67 \mathrm{pp}$.

[11]. Rembialkowska E (2003) Organic farming as a system to provide better vegetable quality. ActaHortic 604:473-479
[12]. Schmitt A, Jahn M, Kromphardt C, Krauthausen HJ, Roberts SJ, Wright SAI, Amein T, Forsberg G, Tinivella F, Gullino ML, Wikström M, Wolf J, Groot SPC, Werner S, Koch E (2006) STOVE: seed treatments for organic vegetable production. In: Presented at the European joint organic congress, Odense, Denmark, 2 pp.

\section{Cite this Article}

C. Manoharan, "Scope of Organic Farming Vegetable Cultivation", International Journal of Scientific Research in Science and Technology (IJSRST), Online ISSN : 2395-602X, Print ISSN : 2395-6011, Volume 8 Issue 5, pp. 220-224, September-October 2021. Available at

doi : https://doi.org/10.32628/IJSRST218519

Journal URL : https://ijsrst.com/IJSRST218519 